\title{
ON AN ABORIGINAL IMPLEMENT, BELIEVED TO BE UNDESCRIBED, AND SUPPOSED TO BE A HOE.
}

\author{
By R. Etheridge, Junr., \\ (Paleontologist to the Australian Museum, and Geological \\ Survey of New South Wales).
}

(Plate vi.)

This remarkable object, that at first sight would be pronounced as coming from one or other of the Pacific Islands, rather than the Australian Continent, I am assured by Mr. Harry Stockdale, whose name I have had occasion to mention in former communications to this Society, was obtained by Mr. Alexander Gilchrist, F.R.G.S., "on the head waters of the Endeavour River, Northern Queensland, about one hundred and fifty miles inland."*

The Endeavour River is in Cape York Peninsula, about S. Lat. $15^{\circ}$, at Cooktown.

Mr. Gilchrist continues- "The tribe was small in numbers, about seventy, but possessed a lot of weapons ; they were Myalls, $\dagger$ although friendly to me."

But one use can be assigned to this implement, that of digging, and for the sake of brevity will be referred to hereafter as a "hoe." It consists of a stick with a diameter of three and a-half inches, that has been chopped off short above, and with an iron tool fashioned into a handle below, and the clean chops of the cuts show that the operator was no novice in the practice of the

\footnotetext{
* In a letter to Mr. Steckdale. +i.e., wild blacks.
} 
instrument used. At about the centre of the unexcised part, or head as it may be termed, a hole has been bored, one and a-half inches in diameter. This head is six inches long, and the excised portion or handle about nine inches. Introduced into the hole, is the columellar portion of the body whorl of the large Melon shell, probably Melo diadema, Lamk., the outer edge of the fragment, or what would be the anterior end of the whorl, being ground to a cutting edge, by friction from the outside, producing a slight bevel. As the shell portion is too small for the hole, the former has been wedged in by four pieces of circular stick, soft wood, which project on the outside, and the shell blade is thus held in position. It is six inches in length.

I can only imagine this to have been meant for a hoe, and, although of the roughest description, it was, no doubt, tolerably well adapted to the use for which it was meant, the roughest description of husbandry.

It has been asserted on more than one occasion that the Australian Aborigines were collectively quite devoid of any knowledge of husbandry, even in its most elementary form. This generalisation is, however, a mistake, similar to many other mistakes that have been made by writers with the view of bolstering up the old preconceived and erroneous idea that the Australian Aborigine represents one of the most, if not the most degraded variety of the human race.

Sir George Grey has described* the method of yam digging employed by the natives generally with the yam-stick. The stick is driven firmly into the ground with the right hand and shaken, so as to loosen the earth, "which is scooped up and thrown out with the fingers of the left hand, and in this manner they dig with great rapidity."

Sir Thomas Mitchell also, in his account of tropical Australia, describes "ground tilled by the natives." He states: $\dagger$ " We

* N. - West and Western Australia, 1841, ii. p. 293.

+ Tropical Australia, 1848, p. 274. 
crossed some patches of dry swamp where the clods had been very extensively turned up by the natives. . . . The whole resembled ground broken up by the hoe."

With regard to the West Australians, we are informed by $\mathrm{Mr}$. A. C. Gregory* that "the natives of the west coast of Australia are in the habit, amongst other things, of digging up yams as a portion of their means of subsistence. . . . In digging up these yams they invariably re-insert the head of the yams so as to be sure of a future crop, but beyond this they do absolutely nothing which may be regarded as a tentative in the direction of cultivating plants for their use."

I am of opinion that this hoe is not of Australian Aboriginal manufacture, but simply an adoption by the tribe from whom it was obtained of an implement imported from one of the Torres Straits islands in the ordinary way of barter-a well-known practice held by the northern coastal tribes, in common, in fact, with those of the whole Continent. Mr. E. Beardmore speaks of a hoe, almost identical in construction to the present implement, from Mowat, Daudai, New Guinea. He says $\dagger$ " It is made from a piece of melon shell (Cymbium) inserted into a hole in a rough wooden handle, the shell being wedged in by one or two pieces of wood. . . This rude hoe is only used on soft ground." D’Albertis also figures $\ddagger$ a very similar implement, as a "shell spade," from the interior of New Guinea, as then known, but no definite locality is given. The blade is mounted in a precisely similar manner to our example through a hole in the handle, D'Albertis also figures $\$$ two unmounted blades, also identical in character to the present implement, from Moatta, N. Guinea.

That the present implement is not of Aboriginal manufacture, is, I think, conclusively proved by the drilling of the hole for the

* Journ. Anthrop. Inst. Gt. Brit. and Ireland, 1887, xvi. p. 131.

† Journ. Anthrop. Inst. Gt. Brit. and Ireland, 1890, xix. p. 468.

$\ddagger$ New Guinea, 1880, ii. pl. opp. p. 378, f. 11.

$\S$ Loc. cit. i. pl. opp. p. 266, f. 12 and 13. 
reception of the blade. The Australian Blacks were quite unacquainted with the art of hafting by drilling, union between any two parts of their weapons or implements being always effected by grasping or tying and cementing. A very excellent illustration of this is on record. General Pitt-Rivers (Col. A. Lane-Fox) states* that at an old native camping place, a European axe-head was found, the hole of which the natives, unable to comprehend its object, had carefully filled with their cementing medium, and hafted by means of a withy, bent round the outside of the axe-head, in accordance with their traditional custom.

* Report Brit. Assoc. Adv. Sci. for 1872 [1873], p. 160. 


\section{$2 \mathrm{BHL}$ Biodiversity Heritage Library}

Etheridge, Robert and Melo-Costa, Wanessa de. 1894. "On an aboriginal implement, believed to be undescribed, and supposed to be a hoe." Proceedings of the Linnean Society of New South Wales 9, 109-112. https://doi.org/10.5962/bhl.part.18096.

View This Item Online: https://www.biodiversitylibrary.org/item/29750

DOI: https://doi.org/10.5962/bhl.part.18096

Permalink: https://www.biodiversitylibrary.org/partpdf/18096

\section{Holding Institution}

MBLWHOI Library

\section{Sponsored by}

MBLWHOI Library

\section{Copyright \& Reuse}

Copyright Status: NOT_IN_COPYRIGHT

This document was created from content at the Biodiversity Heritage Library, the world's largest open access digital library for biodiversity literature and archives. Visit BHL at https://www.biodiversitylibrary.org. 